\title{
The ICC Should Not Encourage Occupation
}

Uri Weiss

Van Leer Jerusalem Institute

Follow this and additional works at: https://digitalcommons.tourolaw.edu/lawreview

Part of the Criminal Law Commons, International Humanitarian Law Commons, and the International Law Commons

\section{Recommended Citation}

Weiss, Uri (2021) "The ICC Should Not Encourage Occupation," Touro Law Review. Vol. 37: No. 2, Article 11.

Available at: https://digitalcommons.tourolaw.edu/lawreview/vol37/iss2/11

This Article is brought to you for free and open access by Digital Commons @ Touro Law Center. It has been accepted for inclusion in Touro Law Review by an authorized editor of Digital Commons @ Touro Law Center. For more information, please contact Iross@tourolaw.edu. 


\title{
THE ICC SHOULD Not ENCOURAGE OCCUPATION
}

\author{
Uri Weiss*
}

\section{Preface AND Summary}

The International Criminal Court (the ICC) has neither universal jurisdiction (jurisdiction that is not dependent on the consent of the parties), nor consent-based jurisdiction (jurisdiction that depends on the mutual consent of the two involved states). The ICC does have jurisdiction in cases in which the conduct to be judged took place in a State that accepts the Rome Statute (that declares that the crimes within the jurisdiction of the Court shall not be subject to any statute of limitations).

Universal jurisdiction would provide the best protection of human rights. Universal jurisdiction does not obtain. It obtains only partially. That is to say, the ICC, which is the institution that is closest to having universal jurisdiction, has only partial universal jurisdiction. The assumption is common that partial jurisdiction is second best. This is not always true. The shift of the ICC from traditional consentbased jurisdiction to a partially universal jurisdiction might weaken human rights protection in some scenarios. The ICC may provide the following undesirable incentives: it might encourage an occupying state to continue the occupation in order to prevent the emerging free state from becoming a party to the Rome Statute and, especially, from accepting its jurisdiction retroactively. It may likewise encourage the occupying state to initiate a civil war in the occupied state as a means of discouraging it from joining the ICC. Moreover, it may encourage

\footnotetext{
* Dr. Uri Weiss, a Polonsky Fellow, Van Leer Jerusalem Institute. I wish to thank Joseph Agassi, Robert P. Barnidge, Jr, Shay Dothan, Eva Dwertmann, Aeyal Gross, Ariel Porat and Kendall Thomas, and an anonymous referee for their very useful comments about my working paper The ICC May Encourage Occupation. I thank the participants in the Annual Conference of the Israeli Law and Economics Association for their remarks.

Proper Disclosure: the author is an amicus curia of the court regarding the jurisdiction of the Court in the situation in Palestine.
} 
the rise of terrorist leadership in the occupying state to discourage the occupied people from striving toward independence and joining the ICC. How should the ICC prevent these undesirable incentives? The simplest manner is, of course, the institution of the right of the occupied people to join the ICC even before the termination of the occupation. The occupying state must not have veto power with regard to the occupied people's capacity to join the ICC. The current inability of Palestine to join the ICC as long as it is occupied comprises an incentive for Israel to continue the occupation.

\section{PeaCe, War, International LaW ANd InCENTIVES}

Robert J. Aumann proposed in his 2005 Nobel Prize Lecture that efforts to bring about world peace should change direction. ${ }^{1}$ The aim of these efforts was to resolve specific military conflicts between neighboring nations. Aumann's suggestion was "that we should shift emphasis and study war in general" by using game theory. ${ }^{2}$ Aumann said that he talks about "the incentives that lead to war, and about building incentives that prevent war." 3 Let us follow this proposal and see where it leads.

Game theory proposes the optimal management of conflict and/or cooperation in some specific situations. It describes them within the framework of one simple scheme or formula on the supposition that it is not a real constraint. For, rather than a study of a particular situation, game theory purports to present the common general principle, put in a rather simple scheme, that allegedly guides many interactions, including war and peace, trade, litigation, and courtship.

Game theory discusses questions, such that what is recommended for a player to do in a given interaction given their preferences. Some game theorists propose predictions about the result of a particular game. The problem is that it is hard to know what game is played, as pointed out by Mario Bunge. ${ }^{4}$ Thus, we should also ask what game is played when we make real life predictions. Some game theoreticians, particularly those of the mechanism design theory, propose what game

\footnotetext{
${ }^{1}$ Robert J. Aumann, War and Peace, Les Prix Nobel 2005, edited by K. Grandin, The Nobel Foundation, Stockholm, 350 (2006).

${ }^{2} I d$.

${ }^{3} I d$.

${ }^{4}$ See generally Mario Bunge, Social Science Under Debate (1998).
} 
to create, and the approach that Uri Weiss and Joseph Agassi develop is that the most important contribution of game theory is by recommending what games should be prevented.

In Game Theory, we analyze behavior of rational players. According to Aumann:

[i]t is a big mistake to say that war is irrational. We take all the ills of the world - wars, strikes, racial discrimination - and dismiss them by calling them irrational. ... [O]nce we understand that [they are rational], . . . we can at least somehow address the problem. ${ }^{5}$

It is important to distinguish between an economically rational player and a philosophically rational player. In Game Theory or in law and economics, when we speak about rational players, we do not speak about players who have critical thought, who challenge their beliefs or try to find proof and refutation, but about players who choose the efficient means to promote their own goals - bad or good. Thus, one may be an absolute pacifist and still think that war is rationalrational in the economic sense. War-loving people are not rational in the philosophical sense, but they are rational in the economic sense when they promote wars. Thus, for example, it is much better to promote peace economics than war economics and to make war industries less profitable.

One may say: but this is a methodology of cost-benefit analysis, so how can it be implemented to international law? Particularly, how can this methodology promote values such as peace and human rights? The answer is that game theory can teach us how to design incentives, such that states prefer peace to war and prefer avoiding war crimes, and which incentives the law must not provide. In order to make war inferior to peace, the mechanism should be such that it will not be worthwhile to prefer aggressive behavior to peaceful behavior or war crimes to legal conduct. Game theory can also help us to investigate how to lead to peaceful and friendly feelings.

In another piece, Aumann argues that The Prisoner's Dilemma ${ }^{6}$ demonstrates that it is not enough for something to be to our mutual

\footnotetext{
${ }^{5}$ Aumann, supra note 1 , at 351 .

${ }^{6}$ Prisoners' dilemma: suppose two people are arrested for possession illegal weapons near a bank in which an armed robbery just took place. The police have strong
} 
advantage for us to achieve cooperation. ${ }^{7}$ Even when cooperation is to your advantage and to my advantage, the incentives can still lead us to non-cooperation - to a result that is disastrous for both of us. It is not enough to say: "Let's cooperate, let's not go to war, let's not fight." We have to pay attention to incentives when we are analyzing a situation. It is not enough to say, "let's make love, not war." The incentive has to be there. ${ }^{8}$ Aumann argues that a statement in this direction was made also by Barack Obama in his Nobel Prize Lecture: "The belief that peace is desirable is rarely enough to achieve it." Let us refer: it is true that this belief is not enough to achieve peace, but the belief that peace is desirable is a sine qua non to prevent wars, and trust sometimes makes the difference between war and peace. International institutions should be designed by peace lovers such that they will prevent wars and war crimes, and if they can create peaceful feeling, then it will be a great advantage for them. The biggest achievement of the European Union is that if one EU state can occupy another EU state and win the war for sure, and even without paying with the blood of their soldiers, then their citizens will resist it. This is a big advantage of the EU model on the Pax Romana model. ${ }^{10}$ When nations maintain peaceful feelings, then the cost of mistakes becomes

enough evidence to charge them with the minor infringement that incurs a lenient penalty but not enough evidence to charge them with the severe infringement that incurs a severe penalty. To achieve that, the police isolate them and propose to each of them a plea bargain. The options that the game offers are these: if they both betray each other, they will both receive a medium penalty; if they cooperate with each other and keep silent, then they will both receive the lenient penalty. If only one defects, then that one will walk, and the other will receive the severe penalty. The outcomes then are A (freedom), B (lenient penalty), C (medium penalty), and D (severe penalty):

\begin{tabular}{|l|l|l|}
\hline & Cooperate & Defect \\
\hline Cooperate & B, B & D, A \\
\hline Defect & A, D & C, C \\
\hline
\end{tabular}

${ }^{7}$ Robert J. Aumann, Game Engineering, Hebrew U. Jerusalem, CTR FOR STUd. RATIONALITY 11 (2009).

${ }^{8}$ See id.

9 Barack H. Obama, A Just and Lasting Peace, NobelPrize.ORG, http://nobelprize.org/nobel_prizes/peace/laureates/2009/obama-lecture_en.html (last visited May 3, 2021).

${ }^{10}$ See generally Uri Weiss \& Joseph Agassi, The Game Theory of the European Union Versus the Pax Romana, DEPAUL L. REV. (forthcoming), https://papers.ssrn.com/sol3/papers.cfm?abstract_id=3621621. 
much lower. Sometimes, even though the incentive not to enter war is there, the decision maker will dismiss it. However, if the decision maker thinks that peace is desirable, it will make all the difference between war and peace. Since mistakes are inevitable, it is not enough that the incentive will be there.

We are interested in preventing wars, occupations, war crimes, and crimes against humanity; therefore, we will analyze the incentives provided by the ICC from a general point of view, and we will analyze the behavior of the occupying state and the occupied people as economically rational players, i.e., players who respond to incentives in a way that promotes their own goals. When we analyze the incentives of the ICC, we conclude that unfortunately, the ICC in its current legal structure, may encourage in some conditions occupation, war crimes, and civil wars; and hence, we need to amend or interpret the law regarding the right to join the Rome Statute, such that the occupier cannot prevent the occupied from joining the Statute.

This paper may present an example to Aumann's proposition: "the incentive of the players interact in complex ways, and lead to surprisingly, often counter-intuitive results." implements the approach that Uri Weiss developed with Joseph Agassi:

[W]e suggest that the most significant achievement of game theory is not in the design or in the applications of games but in the suggestions of what games it is unwise to play. Here we follow Popper, who said, politically, preventing pain or suffering has priority over creating pleasure. ${ }^{12}$ Obviously, in game theory, prevention is also much easier than application, because every game requires some conditions for its very applicability, and these are never too clear and seldom parts of game theory proper. ${ }^{13}$

We will present a potentially dangerous game that the Rome Statute may create, and we will search for mechanisms to prevent this dangerous game. In other words, we will investigate which games of

${ }^{11}$ Aumann, supra note 1, at 351.

${ }^{12}$ KARL POPPER, THE OPEN SOCIETY AND ITS ENEMIES 442 (1945).

${ }^{13}$ Uri Weiss \& Joseph Agassi, How Game Theory Encourages Peace (forthcoming); see The Game Theory of the European Union Versus the Pax Romana, supra note 10. 
partial universal jurisdiction should be prevented. In order to prevent bad games, it is particularly recommended to reject the claim that an occupied people cannot join the ICC. Otherwise, the occupier will have an incentive to preserve the occupation. In the word of the Talmud: "so that the sinner does not profit [from his sin]:" 14 the law should not comprise incentive to $\sin .^{15}$

\section{THE ICC JURISDICTION}

\subsection{The Historical Background of the ICC}

The Rome Statute is due to a political compromise. ${ }^{16}$ On the question of jurisdiction, the British proposal and the German proposal differed. A proposal by South Korea was a compromise between them, and it was the most popular at that time. ${ }^{17}$ The British proposal was this: in the case of non-state parties, jurisdiction of the court should hold if, and only if, both the custodial state and the territorial state agree to it. ${ }^{18}$ By contrast, the German proposal was this: the court should have universal jurisdiction and no agreement of either side was required. ${ }^{19}$ The German proposal rested on the idea that regarding core crimes, international law already commands universal jurisdiction; the

\footnotetext{
${ }^{14}$ Mishnah Challah 2:7.

15 The ICC prosecutor wrote:

Significantly, there appear to be several reasons why a case-specific application of the Montevideo criteria to Palestine is warranted. First, the internationally recognised right to self-determination of the Palestinian people in the Occupied Palestinian Territory. Second, the detrimental impact of the ongoing breaches of international law on Palestine's effective authority over the Occupied Palestinian Territory and on the realisation of the right of self-determination of its people. Finally, the bilateral recognition of Palestine afforded by at least 138 States.
}

International Criminal Court, Prosecution Request Pursuant to Article 19(3) for a Ruling on the Court's Territorial Jurisdiction in Palestine, No. ICC-01/18 (Jan. 22, 2020), https://www.icc-cpi.int/CourtRecords/CR2020_00161.PDF.

Our game theoretical analysis strengths her second argument.

16 See Philippe Kirsch \& Darryl Robinson, Reaching Agreement at the Rome Conference, in THE Rome STATUTE of THE InTERnATIONAL CRIMINAL COURT: A COMMENTARY ch. 2.3 (Antonio Cassese, Paola Gaeta \& John R.W.D Jones eds., 2002).

${ }^{17}$ See Proposal of the Republic of South Korea, UN Doc. A/CONF.183/C.1/L.6 (June 18, 1998).

${ }^{18}$ See Kirsch \& Robinson, supra note 16.

${ }^{19} \mathrm{Id}$. 
international court should possess the same authority as the national courts. The Korean proposal was:

that by becoming a Party a State would be considered to have accepted the jurisdiction of the ICC. The jurisdictional nexus was that anyone or more of four involved States Parties have consented to the Court exercising jurisdiction over a case: either the territorial State, State of nationality of the accused, State of nationality of the victim, or custodial State. ${ }^{20}$

\section{a. The ICC Jurisdiction Under the Rome Statute}

The Rome Statute reflects a political compromise between the above competing proposals. The ICC jurisdiction is determined by Article 12 of the Rome Statute:

Preconditions to the exercise of jurisdiction

A State which becomes a Party to this Statute thereby accepts the jurisdiction of the Court with respect to the crimes referred to in article 5.

In the case of article 13, paragraph (a) or (c), the Court may exercise its jurisdiction if one or more of the following States are Parties to this Statute or have accepted the jurisdiction of the Court in accordance with paragraph 3:

The State on the territory of which the conduct in question occurred or, if the crime was committed on board a vessel or aircraft, the State of registration of that vessel or aircraft;

The State of which the person accused of the crime is a national.

If the acceptance of a State which is not a Party to this Statute is required under paragraph 2, that State may, by declaration lodged with the Registrar, accept the exercise of jurisdiction by the Court with respect to the crime in question. The accepting State shall cooperate

20 Sharon A. Williams, The Rome Statute on the International Criminal CourtUniversal Jurisdiction or State Consent-To Make or Break the Package Deal, 75 INT. L. STUD. 541, 546 (2000). 
with the Court without any delay or exception in accordance with Part 9. ${ }^{21}$

According to Rome Statute, the jurisdiction of the ICC depends on the consent of the states. If a state accepts the jurisdiction of the court, the court will have jurisdiction over it. On the other hand, when a state accepts its jurisdiction, then the ICC has jurisdiction to judge war crimes that have been committed on its territory, even by foreign forces. $^{22}$ This means that if an invaded state accepts the jurisdiction of the ICC, then the soldiers of the invading state can be investigated and prosecuted although the latter has never accepted the jurisdiction.

Furthermore, according to Article 11, paragraph $2^{23}$ and Article 12, paragraph 3 of the Rome Statute, a state can accept the ICC's jurisdiction with respect to crimes that had been committed since the entry into force of the Rome Statute, which was on July 1, 2002. ${ }^{24}$ This is even if those crimes had been committed before that state joined. This means that if a country were to join the ICC on January 1, 2022, it could accept the authority of the court even over crimes committed between January 7, 2002 and January 1, 2022, and also, of course, the authority of ICC jurisdiction over future crimes.

To conclude: first, when a state accepts the jurisdiction of the court, the jurisdiction is also valid for crimes committed on its territory, even by foreign forces. Second, it can accept the ICC's jurisdiction even over crimes that were committed before it joined but since July 2002. Those two propositions lead to the conclusion that a state may accept the ICC's jurisdiction over crimes that were committed on its territory by foreign forces before that state became party to the Rome Statute.

It should be noted that the rule is that " $[\mathrm{t}]$ he ICC may only exercise jurisdiction where national legal systems fail to do so, including where they purport to act but in reality are unwilling or

${ }^{21}$ Rome Statute of the International Criminal Court art. 12, July 1, 2002, 2187 U.N.T.S 90 [hereinafter Rome Statute].

${ }^{22} \mathrm{Id}$.

${ }^{23}$ Rome Statute art. 11 ("If a State becomes a Party to this Statute after its entry into force, the Court may exercise its jurisdiction only with respect to crimes committed after the entry into force of this Statute for that State, unless that State has made a declaration under article 12, paragraph 3.").

${ }^{24}$ Rome Statue of the International Criminal Court, July, 17 1998, 2187 U.N.T.S. 38544. 
unable to genuinely carry out proceedings." 25 Furthermore, "the Court shall determine that a case is inadmissible where: . . . [t] he case is not of sufficient gravity to justify further action by the Court." 26 For example, the General prosecutor rejected the request to investigate Israel regarding Mavi Marmara because she found that the crimes did not meet the demand of gravity. ${ }^{27}$

\subsection{A Particular Question on the Table of the Court}

In January 2009, the Palestinian Authority's justice minister lodged a declaration with the ICC unilaterally recognizing its jurisdiction for "acts committed on the territory of Palestine since . . . July [1,] 2002." ${ }^{28}$ However, the prosecutor of the ICC has rejected the request. The Office of the Prosecutor announced that it could not act on the Palestinian declaration because Article 12 of the Rome Statute established that only: "a '[s]tate' [could] confer jurisdiction on the [c]ourt" and "deposit an instrument of accession with the SecretaryGeneral of the United Nations. In instances where it is controversial or unclear whether an applicant constitutes a '[s]tate', it is the practice of the Secretary-General to follow or seek the General Assembly's directives on the matter." 29

Mahmoud Abbas, the chairman of the Palestine Liberation Organization and the president of the Palestinian National Authority, wrote on May 17, 2011, in the New York Times:

Palestine's admission to the United Nations would pave the way for the internationalization of the conflict as a legal matter, not only a political one. It would also pave

\footnotetext{
25 International Criminal Court, Informal Expert Paper: The Principle of Complementarity in Practice 3 (2003), https://www.icccpi.int/NR/rdonlyres/20BB4494-70F9-4698-8E30907F631453ED/281984/complementarity.pdf.

${ }^{26} I d$. (quoting Rome Statute art. 17(1)(d)).

${ }^{27}$ International Criminal Court, Victims' Response to the "Application for Judicial Review by the Government of the Comoros" of 2 March 2020, No. ICC-01/13-107 (May 4, 2020), https://www.icc-cpi.int/CourtRecords/CR2020_01778.PDF.

${ }^{28}$ Palestinian National Authority Ministry of Justice, Declaration Recognizing the Jurisdiction of the International Criminal Court, (Jan. 21, 2009), https://www.icccpi.int/NR/rdonlyres/74EEE201-0FED-4481-95D4C8071087102C/279777/20090122PalestinianDeclaration2.pdf.

29 International Criminal Court, Situation in Palestine, https://www.icccpi.int/NR/rdonlyres/C6162BBF-FEB9-4FAF-AFA9-

836106D2694A/284387/SituationinPalestine030412ENG.pdf.
} 
the way for us to pursue claims against Israel at the

United Nations, human rights treaty bodies and the International Court of Justice. ${ }^{30}$

On November 29, 2012, the General Assembly "grant[ed] Palestine non-member observer State status at the [UN]." ${ }^{31}$ Moreover, "on January 1, 2015, the Government of Palestine lodged a declaration under Article 12(3) of the Rome Statute accepting the jurisdiction of the International Criminal Court (ICC) over alleged crimes committed 'in occupied Palestinian territory, including East Jerusalem, since June 13, 2014." "32 "On January 2, 2015, the Government of Palestine acceded to the Rome Statute by depositing its instrument of accession with the UN Secretary-General. The Rome Statute entered into force on April 1, 2015." 33 "On May 22, 2018, pursuant to Articles 13 (a) and 14 of the Rome Statute, the Government of Palestine ("Palestine"), a State Party to the Rome Statute, referred to the Prosecutor the situation in Palestine since ... June [13,] 2014, with no end date." "On . . . December [20,] 2019, the ICC's Chamber also received the Prosecution request for a ruling on the Court's territorial jurisdiction in Palestine. (the 'Prosecutor's 20 December 2019 Request')." 34

On January 21, 2020, the Chamber issued the 'Decision on the Prosecutor's Application for an extension of the page limit,' thereby: (i) granting the Request for an Extension of the Page Limit; (ii) rejecting in limine the Prosecutor's December 20, 2019 Request; (iii) inviting the Prosecutor to file a new request of no more than 110 pages, including any references to the Supplementary Information; and (iv) instructing the Registrar to strike from the record of the Situation and

\footnotetext{
${ }^{30}$ Mahmoud Abbas, The Long Overdue Palestinian State, N.Y. TIMES (May 17, 2011), https://www.nytimes.com/2011/05/17/opinion/17abbas.html.

${ }^{31}$ General Assembly Grants Palestine Non-member Observer State Status at UN, UN NEWS (Nov. 29, 2012), https://news.un.org/en/story/2012/11/427052-generalassembly-grants-palestine-non-member-observer-state-status-un.

${ }^{32} \mathrm{Md}$. Zakir Hossain, Implication of ICC's Decision to Investigate War Crime in Palestine, DAILY SUN (Feb. 13, 2021, 12:00 AM), https://www.dailysun.com/printversion/details/535515/Implication-of-ICC\%E2\%80\%99s-Decisionto-Investigate-War-Crime-in-Palestine.

${ }^{33}$ International Criminal Court, Report on Preliminary Examination Activities (2016), (Nov. 14, 2016), https://www.un.org/unispal/document/auto-insert-202100/. ${ }^{34} \mathrm{Id}$.
} 
withdraw from the Court's website the Prosecutor's December 20, 2019 Request, its annex, and the Supplementary Information. ${ }^{35}$

On January 22, 2020, "the Chamber received the 'Prosecution request pursuant to article 19(3) for a ruling on the Court's territorial jurisdiction in Palestine" 36 (the 'Prosecutor's Request').

The Prosecutor wrote:

The Prosecutor is satisfied that there is a reasonable basis to initiate an investigation into the situation in Palestine, pursuant to article 53(1) of the Statute. There is a reasonable basis to believe that war crimes have been or are being committed in the West Bank, including East Jerusalem, and the Gaza Strip ("Gaza" or "Gaza Strip"), and the Prosecution has identified potential cases arising from the situation which would be admissible. There are no substantial reasons to believe that an investigation would not serve the interests of justice

-.

notwithstanding her own view that the Court does indeed have the necessary jurisdiction in this situation, the Prosecutor is mindful of the unique history and circumstances of the Occupied Palestinian Territory. Indeed, it is no understatement to say that determination of the Court's jurisdiction may, in this respect, touch on complex legal and factual issues. Palestine does not have full control over the Occupied Palestinian Territory and its borders are disputed. The West Bank and Gaza are occupied and East Jerusalem has been annexed by Israel. The Palestinian Authority does not govern Gaza. Moreover, the question of Palestine's Statehood under international law does not appear to have been definitively resolved. Although the

${ }^{35}$ International Criminal Court, Decision on the Prosecutor's Application for an extension of the page limit, No. ICC-01/18-11 (Jan. 21, 2020), https://www.icccpi.int/CourtRecords/CR2020_00144.PDF.

${ }^{36}$ Portia Karegeya, 8 February 2021 - Decision on Territorial Jurisdiction in Palestine Situation, ICL MEDIA Rev. (Feb. 8, 2021 at 8:43 PM), http://www.iclmediareview.com/8-february-2021-decision-on-territorialjurisdiction-in-palestine-situation. 
Prosecutor is of the view that the Court may exercise its jurisdiction notwithstanding these matters, she is aware of the contrary views. Consequently, in order to seek judicial resolution of this matter at the earliest opportunity-and thus to facilitate the practical conduct of her investigation by placing it on the soundest legal foundation - the Prosecutor exercises her power under article 19(3) of the Statute and respectfully requests Pre-Trial Chamber I ("the Chamber") to rule on the scope of the Court's territorial jurisdiction in the situation in Palestine. Specifically, the Prosecution seeks confirmation that the "territory" over which the Court may exercise its jurisdiction under article 12(2)(a) comprises the Occupied Palestinian Territory, that is the West Bank, including East Jerusalem, and Gaza. ${ }^{37}$

The prosecutor also wrote:

In concluding that the Court has the necessary jurisdiction for this situation - and the territorial scope of this jurisdiction - the Prosecutor has primarily been guided by Palestine's status as a State Party to the Rome Statute since... January [2,] 2015 following the deposit of its instruments of accession with the United Nations ("UN" or "United Nations") Secretary-General pursuant to article 125(3)." And she raised the alternative possibility that "the Chamber could likewise conclude - for the strict purposes of the Statute onlythat Palestine is a State under relevant principles and rules of international law. ${ }^{38}$

On January 28, 2020, the ICC's Chamber invited Israel, Palestine "and victims in the Situation in the State of Palestine, to submit written observations on the Prosecutor's Request no later than

${ }^{37}$ International Criminal Court, Prosecution Request Pursuant to Article 19(3) for a Ruling on the Court's Territorial Jurisdiction in Palestine, No. ICC-01/18-12 (Jan. 22, 2020), https://www.icc-cpi.int/CourtRecords/CR2020_00161.PDF.

${ }^{38} I d$. 
. . March [16,] 2020."39 The Chamber also appointed counsel from the OPCV to represent victims in the Situation in the State of Palestine who do not have legal representation for the sole purpose of submitting observations in accordance with paragraph 13 of the present order. ${ }^{40}$ The chamber also invited other "States, organizations and/or persons wishing to provide written observations on the Prosecutor's Request to submit applications for leave to file such observations by no later than ... February [14,] 2020." 41

On February 5, 2021, the ICC's Chamber:

FINDS that Palestine is a State Party to the Statute;

FINDS, by majority, Judge Kovács dissenting, that, as a consequence, Palestine qualifies as ' $[t]$ he State on the territory of which the conduct in question occurred' for the purposes of article 12(2)(a) of the Statute; and

FINDS, by majority, Judge Kovács dissenting, that the Court's territorial jurisdiction in the Situation in Palestine extends to the territories occupied by Israel since 1967, namely Gaza and the West Bank, including East Jerusalem. ${ }^{42}$

It should be noted that one of the majority judges, Judge Marc Perrin de Brichambaut, "conclude[ed] that a determination on a question of jurisdiction pursuant to article 19(3) of the Statute may be made in the specific circumstances of the present proceedings." 43

${ }^{39}$ ICC Pre-Trial Chamber Invites Palestine, Israel, Interested States and Others to Submit Observations, ICC-CPI (Jan. 28, 202), https://www.icccpi.int/Pages/item.aspx?name=pr1512.

${ }^{40}$ International Criminal Court, Order Setting the Procedure and the Schedule for the Submission of Observations, No. ICC-01/18-14 (Jan. 28, 2020), https://www.icccpi.int/CourtRecords/CR2020_00217.PDF.

${ }^{41}$ International Criminal Court, Request for Leave to File Written Observations Regarding the "Situation in the State of Palestine," No. ICC-01/18-28 (Feb. 14, 2020), https://www.icc-cpi.int/CourtRecords/CR2020_00463.PDF.

${ }^{42}$ International Criminal Court, Decision on the 'Prosecution Request Pursuant to Article 19(3) for a Ruling on the Court's Territorial Jurisdiction in Palestine', No. ICC-01/18-143 (Feb. 5, 2021), https://www.icccpi.int/CourtRecords/CR2021_01165.PDF.

${ }^{43}$ International Criminal Court, Pratially Separate Opinion of Judge Perrin de Brichambaut, No. ICC-01/18-143-Anx2 (Feb. 5, 2021), https://www.icccpi.int/RelatedRecords/CR2021_01166.PDF. 


\section{NEW Problems With THE ICC'S JURISDICTION}

\subsection{Incentives for Continuing the Occupation}

One of the new problems with the ICC's jurisdiction is that in some circumstances, it might provide incentives for the occupying state to continue the occupation. This is the case when the occupied people can join the ICC regime after, and only after, the end of the occupation. This may be because the occupied people will not be recognized as having a state, as Israel claims regarding the Palestinians, and it may be because the occupying state may appoint a "puppet leadership" for the occupied people, and it may be because during the period of the occupation, the occupier has the power to extort the occupied people.

The capacity to neutralize the ICC by appointing a "puppet government," or the capacity to extort the occupied state, may also, in particular circumstances, incentivize a state to occupy in order to appoint such a government. First, we will show that the right to join retroactively might encourage the continuation of the occupation; next, we will show that, similarly, even the right to join prospectively might encourage continuation of the occupation. Thus, we strongly recommend preventing those games, first of all by recognizing the right of occupied people to join the ICC.

\section{a. The Effect of the Right to Join Retroactively}

Even if the occupying state was not a party to the statute in 2010 , it can adopt it retroactively in 2022, and then the ICC might have jurisdiction even over crimes that were committed by the occupier during 2010. Thus, on the one hand, the right to join retroactively deters the occupier from violating the Rome Statute, even when the occupied state is not a party to it; this effect of the ability to join retroactively promotes human rights. On the other hand, the occupied people can sometimes join the ICC only after the occupation is ended, and this provides the occupying state with a strong incentive to maintain the occupation. This may be because the occupied people do not meet the condition of statehood, and it may be because the occupied people are controlled by puppet leadership. The occupying power might continue the occupation in order to prevent the occupied people from establishing a free state in order to prevent them from adopting the Rome Statute and possibly accepting ICC jurisdiction 
retroactively. This scenario might happen even if the cost/benefit analysis on behalf of the occupying state would lead it to end the occupation. A mechanism that is intended to protect human rights might become a mechanism of maintaining the occupation.

Let us now show by a game tree that the Rome Statute might prevent the occupier from ending the occupation:

1. We have two players: occupier state and occupied people.

2. This is the sequence of events: first, the occupying state should choose between "continue the occupation" and "end the occupation." If it chooses "continue the occupation," that ends the game, and the result will be "continuation of the occupation." If the occupying state chooses "end the occupation," then the occupied people need to choose between "accepting the jurisdiction of the ICC retroactively," and "not accepting the jurisdiction of the ICC retroactively." If the occupied people choose to accept the jurisdiction of the ICC retroactively, that ends the game, and the result will be "end of the occupation, with the ICC having jurisdiction over previous crimes." However, if the occupied people choose not to accept the jurisdiction of the ICC retroactively, then that ends the game, and the result will be "end of the occupation with the ICC having no jurisdiction over previous crimes."

3. The occupier state's order of priority is: I. end of the occupation with the ICC having no jurisdiction over previous crimes; II. continuation of the occupation; III. end of the occupation with the ICC having jurisdiction over previous crimes.

4. The occupied people's order of priority are: I. end of the occupation with the ICC having jurisdiction over previous crimes; II. end of the occupation with the ICC having no jurisdiction over the previous crimes; III. continuation of the occupation.

5. Both sides know the game.

6 . The occupying state and the occupied people are rational players, and the occupying state knows that the occupied people are rational. Let us now show the situation in the form of a game tree. In the tree, the payoff of the result most favored by a player is 1 (his best result), the payoff of his second-best result is 2 (his second-best result), and that of his worst result is 3 . 


\section{The Game Tree}



end of the occupation, with the ICC having no jurisdiction over the previous crimes

end of the occupation, with the ICC having jurisdiction over previous crimes

$(1,2)$

$(3,1)$

Figure 1. The simple Game of Occupation in the Shadow of the ICC

The result of this Game will be a continuation of the occupation. This is because the occupier chooses first whether to continue or to end the occupation. If the occupying power chooses to end the occupation, then the occupied people will have two alternatives: end the occupation without giving jurisdiction to the ICC or end the occupation with jurisdiction given to the ICC in which case the occupied people will choose to accept the jurisdiction of the ICC, which is the worst result in the eyes of the occupying power. However, if the occupying power chooses to continue the occupation, then the players will obtain a result of occupation without jurisdiction, which is the occupier's second-best outcome. Thus, the occupier will choose not to end the occupation, which leads to its second most favored outcome and to the worst from the point of view of the occupied people. The result of this game will be the "continuation of occupation." Although both players prefer the end of occupation without giving the ICC jurisdiction over the previous crimes, the result will be a continuation of the occupation. ${ }^{44}$

${ }^{44}$ I thank Ariel Porat for his comment that this problem is similar to the problem of defensive medicine. 
In technical language, this is the unique sub-game perfect equilibrium of this game. Thus, this game should be prevented. We will discuss later how to prevent this game; particularly, the occupied people should have a right to join the ICC even before the end of the occupation.

If we change the game such that the occupied people have no possibility of adopting the Rome Statute and accepting its jurisdiction retroactively, then we will achieve an end to occupation, but without jurisdiction, which would be better for both sides. Hence, in this particular situation, it would be better for both sides that the occupied party had had no option of obtaining the jurisdiction retroactively. Actually, in the course of the implicit negotiation between the occupying power and the occupied people, it might be better for the occupied people to make a commitment not to accept the jurisdiction of the ICC retroactively. ${ }^{45}$ Thus, the occupied people might benefit from not having this right. Thus, the above game should be prevented.

One may criticize the above analysis: why does the application of the game theory start where it starts in this analysis - that is, after the occupation has been established? Our reply is that every new legislation is in the middle of some games. This is also the legislation of the Rome Statute: in the Israeli-Palestine case, for example, the new rule enters long after the occupation has been established. ${ }^{46}$

\section{b. The Effect of the Right to Join Prospectively}

Moreover, sometimes, the occupying state might assume that even after its withdrawal, further rounds of war and bloodshed between it and the previously occupied people would be expected to take place; and therefore, the power of the new state to adopt the Rome Statute, even prospectively, might discourage the occupier from ending the occupation. Thus, in order to protect themselves from being exposed

45 About the advantage of being committed during negotiation, see THOMAS $\mathrm{C}$. SCHELling, THE STRATEGY OF CONFLICT 30 (1960).

${ }^{46}$ Moreover, there are many countries that are not members, and their potentially occupier may make it impracticable or impossible for them to join. Of course, making the exit from occupation more expensive may also deter countries from entering into it. However, the cost of making it very costly to end occupation is enormous; sometimes occupation is not a result of a planned action and making the exit from occupation too expensive may lead the occupation to remain. It is much cheaper to deter the beginning of occupation by other means, and this is one of the goals of the criminalization of Aggression by the Rome Statute. 
to the ICC's jurisdiction in subsequent rounds of the conflict, they might continue the occupation. ${ }^{47}$ This is another counterproductive incentive provided by the Rome Statute; if the conflict is expected to continue, then it might be better for the occupied people to undertake a commitment not to join the ICC, even prospectively. Or, to restate this speculation more formally, if and only if, 1) both parties prefer an end of the occupation with no joining the ICC to continuation of the occupation, and the occupying state prefers ending the occupation with no prospective jurisdiction of the ICC to continuation of the occupation; and additionally, 2) the occupied people prefers to join the ICC after the end of occupation rather than not to join it after the end of occupation - under these conditions, they would both benefit from making joining the ICC impossible for the new state formed by the formerly occupied people. In this situation, it would be to the benefit of both of them to relinquish the right to join the ICC. ${ }^{48}$ In this case, the occupation will end but will be transformed to a new order in which the former occupied state has no right to join to ICC. Thus, the above game should be prevented. We will discuss later how to prevent this game.

\footnotetext{
${ }^{47}$ It is realistic to think that the problem with the retroactive jurisdiction holds for both the American Occupation of Iraq and the Israeli Occupation of Palestine, but the problem with the prospective jurisdiction holds for the Israeli Occupation but not to the American one. On the other hand, it may be claimed that if there is a real potential for continuity of the conflict, then it may be rational for the free state of the formerly occupied people not to join retroactively in order not to make the punishment by the ICC a "sunk cost." This means the former occupier power may be encouraged to attack if it is punished, whether it commits new war crimes or not. The conclusion will be that if the effect of the right to join prospectively holds, then the effect of the right to join retroactively does not. However, there will be the problem that this incentivizes the former occupier state to make the continuity of the conflict a real option in order to encourage the new state of the former occupied people not to join retroactively.

${ }^{48}$ The fact that the ICC has only complementary jurisdiction does not abolish the incentive of the occupying state to continue with the occupation. This is so since even if the occupying state is considered to be a state that has a proper legal system that investigates properly the conduct of its prime minister, minister, commanders, and soldiers, the possibility of an intervention by the ICC incentivizes the state's court to apply international criminal law, and the state may wish to block it. Shai Dothan even claimed that the jurisdictional rule that better deters officers depends on the probability of prosecution by the ICC that officers face. Complementarity deters more officers when the probability of prosecution is low, as it is now. See Shai Dothan, Deterring War Crimes, 40 N.C.J. INT'L L. \& COM. REG 739, 747-53 (2015).
} 


\section{c. The Effect of Benvenisty's Proposal}

The proposal of Professor Eyal Benvenisty has highly objectionable results:

To date, Palestine has yet to determine its own territorial claims. Although it has specified certain territory in its referral to this Court, over the years and even quite recently it has presented different territorial positions in other fora, both internationally and internally. Palestine's ambivalence regarding its sovereign territorial claims may be prudent from a strategic political standpoint. However, such selective argumentation pertaining to territorial scope belies legal certainty and coherence. Selective assertions amount to no legally valid assertion. Interests of legal stability, certainty and coherence require that, when entities claim statehood without having exercised effective control over territory, they at the very least define clearly and consistently what territory they claim as their own.

As I have written at length elsewhere, international tribunals fulfill a crucial role in stating what the law is. Being in the unique position to develop and stabilize global expectations entails a heavy responsibility for international adjudicators. Therefore, they must take account of the implications of their judgments beyond the specific case at hand. Similarly, international tribunals must seek coherence when they refer to States' assertions of territorial jurisdiction or when they determine such questions with respect to disputed claims.

Against this background, the absence of a clear and unequivocal erga omnes Palestinian commitment to its territorial pursuits in my view leaves the Court unable to ascertain the "territory of" Palestine for purposes of the Court's jurisdiction without eroding its role as custodian of international legal order. Embracing a bifurcated, case-specific approach to territorial sovereignty would be detrimental to the endeavor of 
creating a coherent legal system, one that resolves potentially contradictory outcomes. ${ }^{49}$

Eyal Benvenisty's proposal obviously encourages the occupier to establish settlements. For, as he observes, the illegal Israeli settlements in the occupied territory prevents decisions regarding the boundaries of the future Palestine state, thereby preventing Palestine from acquiring the right to join the ICC. Moreover, since Palestine is ready to negotiate its boundaries and to swap territories such that part of the settlement will be part of Israel, the proposal amounts to a punishment of Palestine by depriving it of the right to join the ICC. This encourages the occupier to create more settlements and to refuse to make compromises regarding the settlements in any peace negotiation and to increase the vagueness of the border between Israel and Palestine.

\subsection{Incentive to Encourage Terrorist Leadership Among Occupied People}

Another problem with ICC jurisdiction is that it might provide an incentive for the occupying state to encourage terrorist leadership among the occupied people in order to discourage the leadership of the occupied state from adopting the Rome Statute. In this case, even the emerging free state might not join in order prevent the investigation and prosecution of its former leadership. The occupying power might encourage the occupied people to prefer an end to occupation without jurisdiction to an end to occupation with jurisdiction.

This incentive is valid not only in the case of occupied people who are not considered to have a state but also in the case in which it is beyond any doubt that the occupied people have an absolute right to join. The occupying state may be interested in a game "without ICC" and thus may incentivize the occupied state to choose not to join the Rome Statute by convincing leadership that joining the ICC will put them at personal risk. This incentive is valid not only in the case of occupation but also in cases in which one state may significantly influence the identity of the leadership of another state.

49 International Criminal Court, Request for Leave to Submit Amicus Curiae Observations in the Proceedings Relating to the Prosecution Request Pursuant to Article 19(3) for a Ruling on the Court's Territorial Jurisdiction in Palestine, No. ICC-01/18-28 (Feb. 14, 2020), https://www.icccpi.int/CourtRecords/CR2020_00463.PDF. 


\subsection{Incentive to Encourage a Civil War}

A further potential problem that could arise from the ICC's jurisdiction is that the occupying state might encourage a civil war, in which war crimes would be expected to be committed, in order to prevent the emerging free state from joining the ICC. This is because, in such a case, the occupied power would be motivated to prefer no jurisdiction to jurisdiction. This leads to the conclusion that since occupied free people are potentially able to adopt the Rome Statute and to accept its jurisdiction retroactively, the occupying power might have an incentive to encourage the emergence of terrorist leadership among the occupied people and to encourage a civil war in the occupied territory. Moreover, if the Court sees civil war as cancelling the status of the occupied as a state, then it may incentivize the occupied state to encourage a civil war in the occupied territory.

\section{Potential Solutions}

Having pointed out the problems, let us now ask, what are the possible solutions to the ICC's Jurisdiction Problem? In other words, how can we prevent the games in which the occupying state is incentivized to continue with the occupation in order to prevent the occupied state from joining and the game in which one state encourages the other state to make war crimes in order to discourage the other state from joining? We will present and discuss several possible solutions, including those that we recommend resisting, but let us clarify that we strongly support recognizing the right of occupied people to join the ICC even before the end of occupation, such that the occupier will not be incentivized to continue with the occupation.

\section{a. Might the Security Council Solve the ICC's Jurisdiction Problem?}

It could be claimed that the Security Council has the authority to intervene in problematic situations and thereby to solve the ICC's jurisdiction problem. How could the Security Council solve this problem? The first possibility is that, in a specific problematic case, the Security Council would pass a resolution giving jurisdiction to the ICC regardless of the consent of the state involved. This was the case regarding Sudan (United Nations Security Council Resolution 1593), and also regarding Libya (United Nations Security Council Resolution 
1970)..$^{50}$ If the Security Council makes such a resolution, then it will neutralize the incentive to continue with the occupation in order to prevent the occupying state from joining the Rome Statute. However, the problem is that the Security Council is a political organ in which five states possess veto power. It is enough that one of those states has a political interest (of course, in the eyes of its leader) in preventing the ICC from receiving jurisdiction; and also that this state gives its own political interests preference over justice or any other consideration in voting to reject this solution.

The second possibility is that the Security Council would determine that the ICC has no jurisdiction over crimes that have been committed in the specific territory before the end of occupation; and, in specific cases, it might even decide to prevent the emerging state from adopting the Rome Statute, even prospectively. A resolution like this would be similar to the United Nations Security Council Resolutions 1422 and 1487, ${ }^{51}$ in which it was determined that, in a case involving current or former officials or personnel from a contributing state that is not a party to the Rome Statute, over acts or omissions relating to a United Nations established or authorized operation of the United Nations, the ICC shall not commence or proceed with investigation or prosecution of any such case for a twelve-month period, unless the Security Council decides otherwise; in order to base its authority, the Security Council determined that operations established or authorized by the United Nations Security Council are deployed to maintain or restore international peace and security, and it then acts according to Chapter 7. This means of maintaining or restoring international peace and security may give the Security Council authority to block the emerging free state from joining the ICC, under a resolution formulated according to Chapter 7 . However, by adopting a resolution like this, first, we disregard the "friendly face" of partial jurisdiction. The citizens of the new free state will not be protected from war crimes by the ICC. Second, this would politicize the ICC in the sense that strong states would be expected to be relieved of international criminal responsibility. It would create double standards and would impair the legitimacy of the ICC; the ICC would be perceived as an agent of imperialism, and international law violators

${ }^{50}$ S.C. Res. 1593, U.N. Doc. S/RES/1593 (Mar. 31, 2005); S.C. Res. 1970, U.N. Doc. S/RES/1970 (Feb. 26, 2011).

${ }^{51}$ S.C. Res. 1422, U.N. Doc. S/RES/1422 (July 12, 2002); S.C. Res. 1422, U.N. Doc. S/RES/1487 (June 12, 2003). 
might disseminate nationalist feelings and take advantage of them in order to represent themselves as innocent. Third, since it is very hard to pass a resolution in the Security Council, this solution could sometimes be only a theoretical possibility. Again, it would be enough that only one of the five veto-holding states would be interested in the rejection of this solution.

\section{b. Amending the Rome Statute to Abolish Retroactive Adopting}

One solution for the ICC's jurisdiction problem would be to amend the Rome Statute or to give it a narrow interpretation that would exclude the possibility for an occupied party to accept the ICC's jurisdiction retroactively. However, the consequence would be the abandonment of the benefits conferred by the ICC in its capacity as an institution protecting the human rights of occupied people. Such an amendment/interpretation might also present an incentive for one state to occupy another state in order to act in its territory undeterred by the Rome Statute. A state might also make a preemptive strike prior to the other side joining the ICC. When both states might benefit from acting first - by attacking the other or by joining the ICC — this might lead to wars, even when each side would prefer to satisfy the other by not going to war and by not joining the ICC. In addition, this solution would not solve the problem if the occupying state maintained the occupation in order to prevent the emerging free state from joining, even prospectively. The price is very high, but on the other hand, the significance of the alternative might be that the occupation would continue and that the criminals would not be brought to justice. Thus, we might, in certain situations, have no end to the occupation and no protection under international criminal law.

\section{c. Amending the Rome Statute to Have State- Consent Jurisdiction}

The Rome Statute could be amended with a provision that there should be state consent in order to establish jurisdiction. This would prevent the problems pointed out in this article. However, we would then abandon the benefits conferred by the ICC in terms of human-rights protection and would dramatically weaken the incentives for a state to join the ICC. The ICC would not be a mechanism by which a state 
could promise jurisdiction over war crimes against its people that might be committed on its territory. ${ }^{52}$

A partial solution might be to recognize the jurisdiction already held by the ICC but to make it impossible for additional states to join. However, first, this would create a sense of double standards and thereby delegitimize international law; and second, it would provide a strong incentive for states to take measures to prevent new states from joining until the time comes to freeze the legal situation. Thus, even if it were far too costly to maintain an occupation indefinitely, in order to prevent the occupied people from joining the Rome Statute, the occupier might consider it worthwhile to continue the occupation until "freezing day." We presented and discussed this possible solution, but we propose to reject this solution.

\section{d. Agreement as a Potential Solution}

Another solution to the ICC's jurisdiction problem might be a peace treaty in which the occupied state would be obliged not to accept the authority of the court over crimes that had been committed before the withdrawal of the occupying forces and perhaps even obliged not to accept the Rome Statute prospectively. However, this solution presents at least four major disadvantages. First, we know that there are some failures on our way to agreement, such as over-optimism, asymmetric information, and a moral-hazard problem; ${ }^{53}$ agreement is not always achieved, at least not immediately. Second, it involves abandonment of the benefits conferred by the ICC as a mechanism for protecting the human rights of the occupied people and as a mechanism of encouraging the occupied people to ameliorate their resistance. Third, one state might occupy another or even brutalize its occupation in order to coerce the occupied people into undertaking not to join the ICC. Fourth, it is only a partial solution since the occupying state may

\footnotetext{
${ }^{52}$ Another advantage of the Rome Statute that we might abandon by reverting to a state-consent regime is the existing possibility that by joining the Rome Statute, a state may signal its peaceful intention and its trust. By joining the ICC Regime, a state could lessen the prospect of war created when two states mistrust each other to the extent that one of them might launch a preemptive strike.

${ }^{53}$ Moral hazard is the problem that since the future behavior of a party is unobservable, it will be impossible to verify if they perform the contract, what incentivizes them to violate the contract, and what incentivizes the other side not to enter into agreement with them. For example, there is a moral hazard problem regarding the obligation of a party not to arm.
} 
fear that this article in the peace treaty will not be recognized as legal by the Court. ${ }^{54}$

\section{e. $\quad$ Strengthening Alternative Mechanisms}

Another solution might be to strengthen other mechanisms of protection under humanitarian law, especially those based on universal jurisdiction. If we decided to cancel the right to join the ICC retroactively, those mechanisms would promote the goal of human rights protection, which would become more essential in the absence of the mechanism of the ICC. However, even if we decided to keep the right to join the ICC retroactively, it would be important to strengthen mechanisms to protect human rights, in order to reduce the counter-productive incentive presented by the ICC. A particular mechanism that might protect human rights and mitigate the problem with the ICC might be to recognize universal jurisdictions of thirdparty states. If such third-party states enforced international law on criminals who were citizens of states that were not parties to the Rome Statute, our problem could be mitigated; the counterproductive incentive would be weakened because joining the ICC by the emerging state would now present less risk to the occupying power. Third-state jurisdiction should serve as a complementary mechanism to the ICC; it is not true that in light of the existence of the ICC, there is no need in this mechanism. On the contrary, the need for it becomes stronger as a means to reduce the incentive for the occupier to continue the

${ }^{54}$ The ICC decided:

Arguments were also advanced during the hearing that certain agreements entered into between the United States and Afghanistan affect the jurisdiction of the Court and should be a factor in assessing the authorisation of the investigation. The Appeals Chamber is of the view that the effect of these agreements is not a matter for consideration in relation to the authorisation of an investigation under the statutory scheme. As highlighted by the Prosecutor and LRV 1, article 19 allows States to raise challenges to the jurisdiction of the Court, while articles 97 and 98 include safeguards with respect to pre-existing treaty obligations and other international obligations that may affect the execution of requests under Part 9 of the Statute. Thus, these issues may be raised by interested States should the circumstances require, but the arguments are not pertinent to the issue of the authorisation of an investigation.

International Criminal Court, Judgment on the appeal against the Decision on the authorization of an investigation into the situation in the Islamic Republic of Afghanistan, No. ICC-02/17 OA4 (March 5, 2020), https://www.icccpi.int/CourtRecords/CR2020_00828.PDF. 
occupation and in order to reduce the incentive for states to refrain from joining the ICC themselves. However, this solution presents many problems: first, a third state might not have the capacity to enforce its court decision or even to investigate or prosecute a war criminal who lives in another state. Second, third parties sometimes do not have the political will to bring war criminals from another country to justice, especially when the war criminals are from strong states. This means that this solution cannot address the problem of occupation by strong states, which might violate humanitarian law. The conclusion is that third-state jurisdiction might weaken the negative incentives presented by the Rome Statute, but it cannot eliminate them. Thus, this might be only a partial solution to the ICC problem. In addition, this solution would create a perception of double standards, and this third state would lose its legitimacy for intervening in order to prevent war crimes in other states. However, we can also point out the "friendly face" of this solution: it would improve the situation. It is better for a state to enforce international law if, and only if, it has the capability to do so than for it to completely avoid doing so. This applies especially in cases in which the potential war criminal cannot know beforehand whether they are going to be brought to justice in this third state; in such cases, the possibility might deter those potential war criminals. In addition, the punishments in those cases should be enhanced in order to reinforce the deterrence. Furthermore, this mechanism would be more effective in human rights protection if it were adopted by a variety of states and if states agreed to extradite war criminals. However, even if this solution were adopted, we would still have the ICC problem; therefore, we wish to also suggest a modification of this solution. On the one hand, the right to join the ICC retroactively might be cancelled and, on the other hand, the thirdparty universal jurisdiction mechanism could be strengthened in parallel. The result would be that we would eliminate the counterproductive incentive provided by the Rome Statute but would still retain partial protection of human rights. However, this would not eliminate the incentive for a state to continue its occupation in order to prevent the emerging state from joining the ICC prospectively. 


\section{f. $\quad$ Allowing the Occupied People to Adopt the Rome Statute}

Another solution to the ICC's jurisdiction problem would be to recognize the legal right of the occupied people to accept ICC's jurisdiction even before they achieve their independence; this acceptance could be exercised by their representatives. For example, the PLO was recognized as the representative of the Palestinian people before the international community. ${ }^{55}$ According to this suggested solution, recognized representatives should also be authorized to adopt the Rome Statute, even if the occupying people have no state. We strongly recommend this solution.

The abovementioned proposed solution of allowing the occupied people to adopt the Rome Statute offers several benefits. First, if the occupied people became a party to the statute, this would remove the incentive for the occupying state to maintain the occupation in order to prevent the occupied people from joining the ICC. Second, it could confer international legal protection on people who need it; a main objective of international law is to protect people under occupation. In addition, it would provide the occupying state with an incentive to end the occupation since war crimes are almost an inherent feature of occupation. Third, it would provide an incentive to the occupied people to civilize their resistance and especially to avoid terrorism. This is because from the moment they ratify the Rome Statute, they would be exposed to the possibility of international criminal processes, whereas if they followed a line of legal resistance, then they could join the ICC without fearing to be brought to justice. Thus, they will be incentivized to refrain from terrorism both because of the deterrence of international law and in order to make it practicable for them to join the ICC, now or in the future which could in turn deter the occupier from committing war crimes. However, this solution is not perfect. It could not work if the occupier appointed a "puppet government" and, furthermore, would present the occupying power with an incentive to nominate such a government. Second, it also could not work if the occupied people, who are politically weak, had no recognized representative, and a strong occupier might also prevent such recognition. In fact, the occupier would be presented with an incentive to block recognition of the representative of the occupied people. Furthermore, the solution of conferring power to adopt the

${ }^{55}$ See U.N. GAOR, 29th Sess. Supp. No 21, Doc. A/RES/3236 (Nov. 22, 1974). 
Rome Statute on the representative of the occupied people would not be satisfactory if the representative is a despot responsible for war crimes or crimes against humanity. However, the future independent state might accede to the Rome Statute since it would not object to its despot being brought to justice. Thus, in this case, the occupying state would still have a strong incentive to maintain the occupation. Furthermore, the occupying state still would have an incentive to provoke war crimes by the occupied people and also civil war among them in order to discourage them from joining the ICC. The occupying state could threaten and harass the occupied people, possibly persuading them that joining the ICC would not be a rational step for them.

Our proposal is to recognize the right of the occupied people to join the ICC even before they become a state. The same logic leads to other similar conclusions such that the international community should recognize the right of the occupied people to establish their own state even before the end of the occupation. The International Criminal Court should recognize their declaration of independence even if they do not have effective control. The particular moral from our discussion is that the International Criminal Court should recognize the right of Palestine to join the Rome Statute, at least prospectively, even before the end of occupation. Otherwise, the court may incentivize Israel to continue with the occupation.

\section{g. Recognition of Hypothetical Acceptance of ICC Jurisdiction}

Giving power to undemocratic representatives is sometimes not enough. So, how can we overcome the problems inherent in the solution that involves giving the authority to the representative? The remedy for this agency problem might be to recognize a hypothetical acceptance of the jurisdiction. When, for example, the ICC determines that it is in the best interest of an occupied people to join the ICC, then the ICC should become their hypothetical representative in accepting its jurisdiction, especially when they have no realistic possibility to accept it by themselves. It will dramatically weaken the incentive of the occupier to appoint a "puppet government" in order to prevent the 
occupied people from joining. It would be a step toward a perfect universal jurisdiction, which is, in my opinion, the optimal solution. ${ }^{56}$

The last solution, i.e., of giving power to the representative of the state to join, or recognizing its hypothetical consent, offers an additional advantage: it solves the problem of an occupier who maintains occupation in order to prevent the emerging free state from joining the ICC, even prospectively. If there were mechanisms that gave the occupied people a practical possibility to adopt the Rome Statute before the end of occupation, then this counterproductive incentive would be eliminated. However, it is not clear that this solution would be acceptable by the international community, even if adopted by the court. The parties who resist universal jurisdiction would be expected to reject this as a step toward universal jurisdiction. Is this proposed solution far enough from universal jurisdiction that it could be accepted by the universal jurisdiction rejectionists? Does the court itself have authority to interpret the Rome Statute in a way that actually invites the universal jurisdiction to enter "via the window" after its entry "via the door" was intentionally excluded by the founding fathers of the Rome Statute? How much should it be considered to be legitimate, and what should be the weight of such considerations?

\section{The Generality of the Problem ${ }^{57}$}

This paper is written in the background of the Israeli-Palestine conflict and the necessity that the international community avoid

\footnotetext{
${ }^{56}$ We wish to make it clear that Rome Statute may be amended such that on the one hand an occupied People will have the right to join the ICC, even before independence and/or the ICC will have authority to recognize hypothetical acceptance of its Jurisdiction, and, on the other hand, a state would no longer have the power to join the ICC retroactively.

57 Recently, Shai Dothan referred to the draft of this paper in order to refute Holtermann's argument that the very existence of the ICC has only deterrence benefits and no deterrence costs. Dothan gave additional examples, such that a country may avoid from intervening in order to prevent war crimes in another country, discouraged by the fear that their intervention will lead to war crimes by them for which they will be investigated and prosecuted. It is actually equivalent to the argument that if the policeperson may be accountable, then they will be incentivized not to intervene. The argument of Dothan is stronger since a policeperson who does not intervene may face sanctions, while a country that does not intervene does not face sanctions, except the loss of prestige; and if a state is
} 
providing incentives to continue with the occupation instead of helping to promoting peace. The International Criminal Court can be used as a mechanism that promotes peace and prevents war crimes. This will be the case if the International Criminal Court recognizes in its jurisdiction regarding the Israeli-Palestine Conflict. However, if the International Criminal court accepts the view that since Palestine is under occupation, Palestine has no right to join, then the court will incentivize Israel to continue with the occupation and it will lead to more wars and war crimes. It will be a disaster for both sides.

Adam Smith was right when he pointed out that the end of colonialism is in the best interest of the colonialist too. ${ }^{58}$ It is also in the best interest of Israel to shift from occupation to peace, and it is also in the best interest of Israel that the court does not decide that since Palestine is not a state, Palestine has no right to join.

This paper presented a refutation to the view that partial universal jurisdiction is always the second-best option to universal jurisdiction. If partial jurisdiction is such that occupied people can join the court only after the end of the occupation, then at least in cases such as the

motivated by imperial prestige, they may intervene in a wrong way. Another example given by Dothan is the marginal deterrence effect of punishment:

if people expect to be punished by the ICC anyway, they may decide to commit more crimes as they might as well be hanged for a sheep as for a

lamb. Moreover, additional crimes can actually reduce the chances of being prosecuted by the ICC if they are targeted at silencing potential witnesses.

Shai Dothan, The ICC is NOT a Slice of Cheese, (J. INT'L CRIM. JUST., Working Paper No. 184, 2019). For the paper of Holtermann, see Jakob von Holderstein Holtermann, A "Slice of Cheese"-a Deterrence-Based Argument for the International Criminal Court, 11 HuM. RTS. REV. 289, 303-04 (2010).

58 See Adam Smith, The Wealth of Nations ch. 7 (1776). He explained the economical mistake of the colonialists by this:

They did not consider that the value of those metals has, in all ages and nations, arisen chiefly from their scarcity, and that their scarcity has arisen from the very small quantities of them which nature has anywhere deposited in one place, from the hard and intractable substances with which she has almost everywhere surrounded those small quantities, and consequently from the labour and expense which are everywhere necessary in order to penetrate to and get at them. They flattered themselves that veins of those metals might in many places be found as large and as abundant as those which are commonly found of lead, or copper, or tin, or iron. The dream of Sir Walter Raleigh concerning the golden city and country of Eldorado, may satisfy us that even wise men are not always exempt from such strange delusions.

Id. 
Israeli-Palestine conflict, the traditional model protects human rights more than the model of the particular partial universal jurisdiction.

There is even a broader moral: it is a great mistake to design international criminal law such that it will be in the best interest of political leaders to continue with a conflict in order to avoid justice. International criminal law is based on imposing individual responsibility. Through this imposition, it personally incentivizes the leader to avoid a criminal policy, but it may also incentivize the leader to choose a policy that gives them de facto personal immunity. Thus, it was a mistake not to give Ghadaffy the option to quit without being brought to justice, and it was also a mistake regarding Assad. Let us explain: In the 1970 resolution regarding Libya, the Security Council made the mistake of the Rome Statute that this article has come to expose. On February 26, 2011, the Security Council decided "to refer the situation in the Libyan Arab Jamahiriya since . . . February [15,] 2011 to the Prosecutor of the International Criminal Court." 59 This means that the Security Council gave the ICC retroactive jurisdiction, which incentivized Gaddafi to preserve his power and provided him with a commitment to continue fighting until achieving his goals rather than incentivizing him to retire by prospective ultimatum. It was a mistake of the Security Council not to give Gaddafi an option to quit without paying for his former crimes.

The court may not be able to bring war criminals to justice yet be able to prevent some states from granting asylum to war criminals. The Arab Spring, and particularly the war in Syria, challenges the institution of the International Criminal Court in this way: some western states prevented the compromise that gives immunity to the Syrian dictator Assad without having the power to bring him to justice or to deprive him of power.

\section{CONCLUSION}

A legal regime of partial universal jurisdiction might provide an occupying state with an incentive to maintain occupation and, sometimes, to spark civil war in the occupied territory and to promote terrorist leadership among the occupied people. These actions might

${ }^{59}$ In Swift, Decisive Action, Security Council Imposes Tough Measures on Libyan Regime, Adopting Resolution 1970 in Wake of Crackdown on Protesters, UN Doc. SC/10187/REV.1

(Feb.

26 ,

2011),

https://www.un.org/press/en/2011/sc10187.doc.htm. 
be carried out in order to prevent the emerging free state from joining the ICC and accepting its jurisdiction over crimes and especially to prevent it from joining retroactively. We have proposed and discuss some possible solutions to this problem, especially the strengthening of the third-party universal jurisdiction mechanism, the granting of occupied peoples the right to join the ICC, and the authorization of the ICC to recognize hypothetical acceptance of its jurisdiction. The occupied people should have a legal right to join the ICC. Particularly, we support the recognition of the right of Palestine to join the ICC. 